EFFICIENT

\title{
Implementasi Permendagri No 113 Tahun 2014 dalam APBDesa
}

\author{
Athar Yaniar Pratama', Lesta Karolina Br. Sebayang² \\ Jurusan Ekonomi Pembangunan, Fakultas Ekonomi, Universitas Negeri Semarang \\ Permalink/DOI: https://doi.org/10.15294/efficient.vii2.30151 \\ Received: January 2018 ; Accepted: March 2018 ; Published: Juny 2018

\begin{abstract}
This study aims to examine and find out the implementation of Permendagri No. 113 of 2014 in Ngesrepbalong Village, Limbangan, Kendal Regency and analyze the obstacles faced by village officials in its implementation. This study uses a qualitative approach with a case study research strategy. Data obtained through interviews and documentation studies. The results of the study show the Implementation of Permendagri No. 113 of 2014 in Ngesrepbalong Village can generally be seen from the following findings: Fund allocation is not appropriate in accordance with the provisions; There is a discrepancy between the list of program activities that have been agreed upon in the village meeting with the details of the activities contained in the RKP table; There is an RKP that does not include a discussion on the evaluation of the previous year's financial use; in the aspect of transparency, the Village Government has implemented it by informing the allocation of funds and the development of their use on information boards in the village office.
\end{abstract}

\section{Keywords: APBDesa, Village Finance, Permendagri}

\begin{abstract}
Abstrak
Penelitian ini bertujuan untuk mengkaji dan mengetahui implementasi Permendagri No 113 tahun 2014 di Desa Ngesrepbalong Kecamatan Limbangan Kabupaten Kendal dan menganalisis kendala yang dihadapi aparatur desa dalam pelaksanaannya.Penelitian ini menggunakan pendekatan kualitatif dengan strategi penelitian studi kasus. Data yang diperoleh melalui wawancara dan studi dokumentasi. Hasil penelitian menunjukkan Implementasi Permendagri No 113 tahun 2014 di Desa Ngesrepbalong dapat dilihat dari temuan berikut ini: Pengalokasian dana tidak tepat sesuai dengan ketentuan; Adanya ketidaksesuaian antara daftar program kegiatan yang telah disepakai dalam musyawarah desa dengan rincian kegiatan yang ada dalam tabel RKP; Terdapat RKP yang tidak mencantumkan pembahasan mengenai evaluasi penggunaan keuangan tahun sebelumnya; pada aspek trasnparansi, Pemerintah Desa telah melaksanakannya dengan menginformasikan pengalokasian dana dan perkembangan penggunaannya pada papan informasi di kantor desa.
\end{abstract}

Kata Kunci: APBDesa, Keuangan Desa, Permendagri

How to Cite: Pratama, A., \& Br. Sebayang, L. (2019). Implementasi Permendagri No 113 Tahun 2014 dalam APBDesa. EFFICIENT Indonesian Journal of Development Economics, 1(2), 179 -190. https://doi.org/10.15294/efficient.vii2.30151

(C) 2019 Semarang State University. All rights reserved

\footnotetext{
Alamat Korespondensi :

Alamat: Gedung L2 Lantai 2 FE Unnes

Kampus Sekaran, Gunungpati, Semarang, 50229

E-mail : efficientjournal@gmail.com
}

ISSN 


\section{INTRODUCTION}

Pemberlakuan Undang-Undang No. 6/2014 tentang Desa beserta peraturan turunannya, yaitu Peraturan Pemerintah No. 43 Tahun 2014 dan PP No. 40 Tahun 2014 tentang Dana Desa, menjadi sejarah lembaran baru dalam tata pemeintahan di Indonesia. Desa sebagai ujung tombak pembangunan berkelanjutan yang berbasis kemandirian masyarakat. Desa diberikan kewenanngan dan sumber dana yang memadai agar dapat mengelola potensi yang dimiliki sehingga dapat meningkatkan ekonomi dan kesejahteraan masyarakat (Kemenkeu, 2017).

Pelaksanaan ketiga peraturan perundangan-undangan tersebut pada tataran operasional diatur di dalam Peraturan Menteri Dalam Negeri (Permendagri) No 113 tahun 2014. Pada Pasal 1 Permendagri No 113 tahun 2014 disebutkan bahwa desa adalah kesatuan masyarakat hukum yang memiliki batas wilayah yang berwenang untuk mengatur dan mengurus urusan pemerintahan, kepentingan masyarakat setempat dan mengurus prakarsa masyarakat, hak asal-usul, dan hak tradisonal. Paradigma baru pembangunan desa seperti yang disebutkan di atas, menjadikan desa yang merupakan satuan hukum otonom memiliki hak dan wewenang dalam mengatur rumah tangga sendiri. Aswandi (2014:1) menyebut pada kondisi ini, desa bukan lagi sebagai figuran saja namun sudah merambah menjadi aktor utama dalam mewujudkan kemandirian dan kesejahteraan masyarakat desa. Demi mewujudkan cita-cita tersebut, diperlukan tata pemerintahan dan tata pengelolaan keuangan desa yang baik termasuk dalam pengelolaan sumberdaya yang ada di desa tersebut.

Keuangan desa adalah semua hak dan kewajiban desa yang dapat dinilai dengan uang baik berupa uang maupun barang. Keuangan desa merupakan keseluruhan anggaran pendapatan dan belanja desa. Sebelum adanya UU Desa dan peraturan turunannya di atas, pendapatan desa bersumber dari pendapatan asli desa, bagian dari hasil pajak daerah dan retribusi kabupaten/kota, alokasi dana desa yang merupakan bagian dari dana perimbangan yang diterima kabupaten/kota, bantuan keuangan dari APBD Provinsi maupun APBD Kabupaten/Kota, hibah dan sumbangan pihak ketiga serta pendapatan lain-lain yang sah. Setelah adanya UU Desa, maka desa mendapatkan sumber pendapatan baru yang dialokasikan dari APBN disebut Dana Desa (DD). Dana Desa mulai diterima secara bertahap sejak tahun anggaran 2015 dan pembagiannya ini dihitung berdasarkan empat faktor yakni luas wilayah, jumlah penduduk, angka kemiskinan dan kesulitan geografis (Ferina, 2016).

Bertambahnya sumber pendapatan desa membutuhkan pengelolaan keuangan yang baik sehingga bisa mencapai tujuan yang diharapkan, yakni kesejahteraan dan kemandirian masyarakat. Pengelolaan keuangan desa merupakan rangkaian kegiatan yang mencakup mulai dari proses perencanaan, pelaksanaan, penatausahaan, pelaporan, hingga pertanggungjawaban keuangan desa. Untuk mewujudkan tata kelola keuangan desa yang baik, perlu dilaksanakan berdasarkan asas-asas sebagaimana yang disebutkan dalam Pasal 2 Permendagri No 113 Tahun 2014 yang meliputi asas transparan, akuntabel, partisipatif, serta dilakukan dengan tertib dan disiplin anggaran.

Asas transparan dalam pengelolaan keuangan desa memberikan keleluasaan kepada masyarakat untuk mendapatkan 
informasi mengenai keuangan desa mereka. Keterbukaan informasi keuangan desa inilah yang diharapkan akan mencegah penyelewengan anggaran dan peruntukan dana pembangunan yang tepat guna (BPKP, 2015). Kemudian, dengan adanya asas akuntabel diharapkan pelaksananaa kebijakan pengelolaan keuangan desa dapat dipertanggungjawabkan kepada masyarakat. Oleh karena itu, asas partisipatif yaitu keterlibatan masyarakat baik secara langsung maupun tidak langsung melalui lembaga perwakilan yang disebut Badan Permusyawaratan Desa (BPD) penting adanya. Anggota BPD merupakan wakil dari penduduk desa berdasarkan keterwakilan wilayah dan ditetapkan secara demokratis. Minimal keanggotaan BPD adalah enam orang dan maksimal sembilan orang, bergantung kemampuan keuangan desa dan kebutuhan (UU No.6 tahun 2014). Selanjutnya, asas tertib dan disiplin anggaran yaitu anggaran yang diterapkan di desa harus dilakukan pencatatan secara konsisten dalam penggunaannya sesuai dengan prinsip akuntansi keuangan di desa.

Pada prakteknya, penerapan pengelolaan keuangan desa yang sesuai dengan peraturan menemui hambatan-hambatan di lapangan. Salah satu permasalahan yang menjadi kendala dalam implementasi Permendagri No 113 Tahun 2014 adalah ketidaksiapan aparat desa dalam pengelolaan keuangan desa, terutama pada aspek kemampuan sumberdaya manusianya dan komitmen. Faktor-faktor ketidaksiapan pengelolaan keuangan desa ini kemudian ditambah dengan minimnya tingkat koordinasi pemerintah dan partisipasi masyarakat desa ketika adanya suatu aturan baru yang pada akhirnya melemahkan fungsi pengawasan masyarakat atas dana pembangunan desa (Ferina, 2016). Lemahnya fungsi pengawasan akan meningkatkan potensi penyelewengan dana desa. Terlebih lagi minimnya partisipasi masyarakat dalam pegawasan penggunaan dan penyaluran dana desa. Setiap desa diharuskan untuk mempersiapkan Anggaran Pendapatan dan Belanja Desa (APBDesa) dengan peruntukan maksimal 30\% digunakan untuk penghasilan tetap dan tunjangan kepala desa beserta perangkat desa lainya, operasional pemerintahan, tunjangan dan operasional BPD, dan insentif rukun tetangga dan rukun warga. Sisanya, sebesar 70\% anggaran harus terserap untuk mendanai penyelenggaraan Pemerintahan Desa, pelaksanaan pembangunan Desa, pembinaan kemasyarakatan Desa, dan pemberdayaan masyarakat Desa (PP No 43 tahun 2014). Pada kenyataannya, ditemukan praktik yang tidak sejalan dengan ketentuan. Salah satu fakta ditemukan di Desa Ngesrepbalong, di mana terjadi ketidaktepatan dalam pengelolaan anggaran dana desa. Berdasarka Laporan Pertanggungjawaban Realisasi APBDesa Desa Ngesrepbalong tahun Angaran 2017 menunjukkan bahwa beban biaya belanja pegawai, operasional, gaji dan insentif aparatur desa mencapai 31,9\%, melebihi 1,9\% dari aturan yang seharusnya. Ditambah lagi, terdapat berbagai progam pada tahun 2017 yang tidak terlaksana yang menyisakan dana sebesar Rp. 66.901.668 atau 5,03\% dari APBDes tahun tersebut.

\section{METODE PENELITIAN}

Pendekatan yang digunakan dalam penelitian ini adalah pendekatan diskriptif 
kuaitatif.Pendekatan dengan kualitatif Miles and Hiberman yaitu pengumpulan data, dimaksudkan untuk memahami fenomena reduksi data, display/penyajian data dan yang terdapat di lapangan melalui gambaran secara menyuluruh dan memperbanyak pemahaman yang mendalam. Sampel pada penelitian ini berjumlah 5 orang yang dilakukan dengan carapurposive sampling. Mereka ditetapkan dan disesuaikan dengan kompetensi dan pengetahuan yang objektif dan terukur dengan penelitian ini yang meliputi; Model analisis data yang digunakan dalam penelitian ini menggunakan model mengambil kesimpulan lalu diverifikasi.

\section{HASIL DAN PEMBAHASAN}

Pengucuran dana desa ke Desa Ngesrepbalong dilaksanakan sejak tahun 2015. Pada perkembangannya, dana desa yang dterima mengalami peningkatan. Adapun peningkatannya ditunjukkan pada gambar berikut:

Gambar 1. Besaran Dana Desa yang diterima Desa Ngesrepbalong 2015-2017

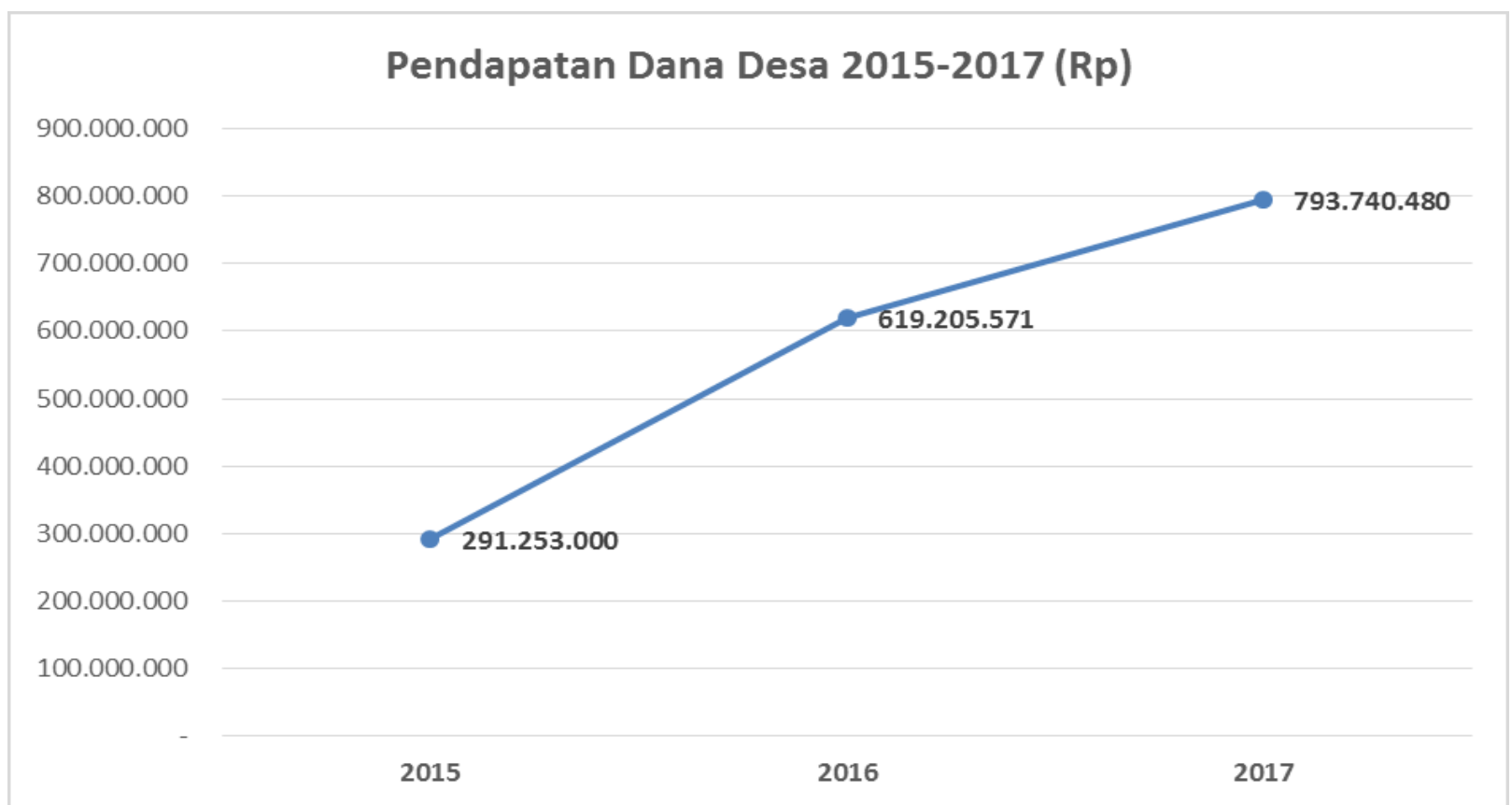

Sumber: Laporan Kerja Pemerintah Desa Ngesrep Balong

Pendapatan dana desa Desa dengan kewenangannya dengan mengacu pada Ngesrepbalong mengalami peningkatan perencanaan pembangunan kabupaten/kota. signifikan pada tahun 2016, yakni mencapai $113 \%$ dari tahun sebelumnya. Kucuran dana Perencanaan Pembangunan Desa meliputi RPJMDesa dan RKPDesa yang disusun secara desa mengalami peningkatan $28 \%$ pada tahun 2017 dibandingkan tahun 2016.

Pemerintah Desa menyusun berjangka dan ditetapkan dengan Peraturan Desa. RPJMDesa digunakan untuk jangka perencanaan pembangunan desa sesuai untuk jangka waktu 1 (satu) tahun. 
Rancangan peraturan Desa tentang RKP Desa dibahas dan disepakati bersama oleh Kepala Desa dan Badan Permusyawaratan Desa untuk ditetapkan menjadi Peraturan Desa tentang RKP Desa. Penggunaan dana APBDesa atau belanja desa oleh Pemerintah Desa diperuntukkan untuk membiayai pelaksanaan kewenangan desa dalam bentuk berbagai kegiatan pembangunan dan pemberdayaan masyarakat desa. Menurut pasal 100 PP Nomor 43Tahun 2014, dijelaskan bahwa belanja desa yang ditetapkan dalam APBDesa harus berdasarkan paling sedikit 70\% $(\geq 70 \%)$ dari jumlah anggaran belanja desa digunakan untuk mendanai penyelenggaraan pemerintahandesa, pelaksanaan pembangunan desa, pembinaan kemasyarakatan desa, dan pemberdayaan masyarakat desa.

Paling banyak 30\% ( $\leq 30 \%)$ dari jumlah anggaran belanja desa digunakan untuk: Penghasilan tetap dan tunjangan kepala desa dan perangkat desa; Operasional pemerintah desa; Tunjangan dan operasional Badan Permusyawaratan Desa; Insentif Rukun Tetangga dan Rukun Warga yaitu bantuan kelembagaan yang digunakan untuk operasional RT dan RW.

Pengalokasian belanja desa disesuaikan dengan kebutuhan desa pada masa mendatang yang sesuai dengan RPJMDesa dan ditetapkan melalui musyawarah pembahasan RKP antara Kepala Desa, BPD, tokoh masyarakat, tokoh agama, dan tokoh pemuda desa setempat. Seperti yang disampaikan Witoyo :

"bahwa Kalau RPJMDes, RKPDes itu berdasarkan hasil musdes karena RPJMDes itu tindak lanjut dari visi misi kepala desa .... Nah, setelah jadi itu melaksanakan sesuai visi misinya tidak terlepas, harus berdasarkan musyawarah desa penyerapan aspirasi dari dusun ke desa itu diputuskan sesuai dengan prioritas".(Wawancara Witoyo, 18 Mei 2018).

Prioritas pembangunan yang di rencanakan di Desa Ngesrepbalong telah ditetapkan di forum Musrembang des. Selain program, Desa Ngesrepbalong juga menetapkan alokasi belanja desa melalui musyawarah seperti yang telah disebutkan, salah satunya ketika menetapkan RKP untuk Tahun 2017 yang diselenggarakan pada tanggal 22 Desember 2017. Hasil musyawarah tersebut menetapkan kesepakan alokasi dana APBDesa. Adapun besaran pendapatan dan belanja pada APBDesa Desa Ngesrepbalong tahun anggaran 2017 ditunjukkan pada tabel 1.

Tabel 1 dibawah ini menunjukkan bahwa pemerintah Ngesrepbalong mengalokasikan dana untuk Bidang Penyelenggaraan Pemerintah Desa lebih daripada batas maksimal yang sudah ditentukan ketentuan, yakni $\leq 30 \%$. Penganggaran berlebih ini menjadikan tidak terlaksanakannya peraturan PP No 43 Tahun 2014. Selain penggunaan dana yang kurang tepat, ditemukan pula ketidaksesuaian antara poin-poin program yang telah disepakai dalam musyawarah desa dalam membahas RKP tahun 2017 (tertuang dalam berita acara musyawarah desa) dengan rincian kegiatan yang ada dalam tabel RKP, diantaranya: (1) Pada bidang pembangunan tertuang pembangunan Sarana MCK sebesar Rp. 84.890.000, padahal pada berita acara tidak disebutkan; (2) Program pengadaan dan pengelolaan sanggar belajar dan sanggar budaya 
yang telah disepakati tidak ada kucuran dana untuk itu.

Tabel 1 Alokasi APBDesa Tahun 2017

\begin{tabular}{|c|c|c|c|}
\hline No & Alokasi & Biaya (Rp) & $\%$ \\
\hline \multirow[t]{19}{*}{ A. } & Pendapatan & & \\
\hline & Dana & & \\
\hline & $(\mathrm{APBN})$ & 826.813 .000 & 47,9 \\
\hline & Alokasi Dana & & \\
\hline & Desa (bagian & & \\
\hline & dana & 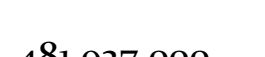 & \\
\hline & perimbangan & 481.927 .000 & \\
\hline & kab.) & & 27,9 \\
\hline & Dana Bagian & & \\
\hline & dari hasil pajak & & \\
\hline & dan retribusi & 37.995 .719 & 2,2 \\
\hline & Bantuan APBD & & \\
\hline & Prov & 35.000 .000 & 2,0 \\
\hline & Pendapatan Asli & & \\
\hline & Desa & 105.708 .000 & 6,1 \\
\hline & Swadaya & & \\
\hline & Masyarakat & 239.492 .060 & 13,9 \\
\hline & IML & & 100 \\
\hline & & 1.726 .935 .779 & \\
\hline \multirow[t]{15}{*}{ B. } & Belanja & & \\
\hline & Bidang & & \\
\hline & Penyelenggaraa & & \\
\hline & n Pemerintah & 544.311 .659 & \\
\hline & Desa & & 31,5 \\
\hline & Bidang & & \\
\hline & Pembangunan & 1.121 .296 .120 & 65,0 \\
\hline & Bidang & & \\
\hline & Pembinaan & 15606000 & \\
\hline & Masyarakat & 45.020 .000 & 2,6 \\
\hline & Bidang & & \\
\hline & Pemberdayaan & 15.000 .000 & \\
\hline & Masyarakat & & 0,9 \\
\hline & JML & & 100 \\
\hline & & 1.726 .233 .779 & \\
\hline
\end{tabular}

Sumber: RKP, 2017
Penyusunan RKP yang mengharuskan adanya pembahasan mengenai evaluasi penggunaan keuangan tahun sebelumnya tidak ditemukan dalam RKP Tahun 2017, berbeda dengan RKP tahun 2015 dan 2016. Tidak adanya penyampaian evaluasi atas pelaksanaan keuangan tahun sebelumnya menjadikan RKP tahun 2017 tidak lengkap dan tidak bisa menggambarkan pelaksanaan pengelolaan keuangan sebelumnya.

Ketidaktepatan penganggaran bisa terjadi, salah satunya disebabkan oleh tidak adanya kontrol, terutama dari BPD. Menurut Nihlatun Nuha (wawancara, 18 Mei 2018) BPD memang terlibat langsung dalam perencanaan, namun tidak ikut serta dalam penganggaran secara langsung.

Selama ini mungkin pemerintahan kemarin belum pernah, kemungkinan karena ini PJ ngih, karena itu berkaitan dengan kepala desanya, mungkin kalau kepala desanya yang mau melibatkan $B P D$ secara langsung itu otomatis bisa, tapi kadang itu kebijakan dari kepala desanya sendiri-sendiri. (Wawancara Nihlatun Nuha, 18 Mei 2018).

Padahal, menurut Permendagri No 113 Tahun 2014 disebutkan bahwa Perencanaan pengelolaan keuangan desa adalah kesepakatan antara pemerintah desa dan BPD. Berdasarkan penjelasan di atas menunjukkan implementasi kebijakan perspektif Edward III yakni struktur birokrasi yang mencakup tentang standar operating prosedur (SOP), pembagian peran kerja dalam pengelolaan keuangan desa tidak terlaksana dengan baik. Selain itu, aspek sumberdaya juga menunjukkan bahwa kemampuan aparatur 
desa dalam merencanakan APBDesa masih kurang.

Pelaksanaan pengelolaan keuangan desa yang merupakan salah satu komponen yang harus disajikan sesuai dengan Permendagri No. 113 tahun 2014. Dijelaskan dalam pasal 24 bahwa dalam pelaksanaannya semua penerimaan dan pengeluaran desa dalam rangka peaksanaan kewenangan dilaksanakan melalui rekening kas desa dengan didukung bukti yang sah dan lengkap, apabila terdapat desa yang tidak mempunyai pelayanan perbankan maka pengaturanya ditetapkan oleh pemerintah kabupaten/kota. Pemerintah desa juga dilarang melakukan pungutan sebagai penerimaan desa selain ditetapkan dalam peraturan desa.

Pelaksanaan anggaran desa Desa Ngerepbalong Kecamatan Limbangan Kabupaten Kendal Tahun 2017, yang sudah ditetapkan sebelumnya terjadi transaksi penerimaan dan pengeluaran desa, semua penerimaan dan pengeluaran desa dalam rangka pelaksanaan hak dan kewenangan desa dilaksanakan melalui rekening kas desa. Hal itu dinyatakan Sofiati, Bendahara desa.

"Iya, semua uang masuk dan keluar melalui rekening desa." (Wawancara, 18 Mei 2018 ):

Berdasarkan hasil observasi lapangan, pelaksanaan kegiatan-kegiatan yang pembiayaaannya bersumber dari Dana Desa sepenuhnya dilaksanakan oleh tim pelaksana desa. Di kantor balai desa penulis jumpai papan informasi yang memuat informasi secara jelas kepada masyarakat mengenai setiap kegiatan fisik. Papan informasi tersebut memuat nama kegiatan, volume kegiatan, besaran anggaran dari DD maupun swadaya masyarakat, dan waktu pelaksanaan kegiatan.

Selain informasi kegiatan fisik yang dilakukan, terdapat pula informasi semua program desa yang masih berjalan maupun yang akan datang. Adanya papan informasi tersebut menunjukkan bahwa Pemerintah Desa Ngesrepbalong telah melaksanakan aspek keterbukaan (transparansi) informasi kepada masyarakat. Dengan demikian, upaya kontrol dari masyarakat bisa dilakukan.

Selain dalam bentuk papan informasi, menurut Triyono, Kepala Desa Ngesrepbalong juga dilaksanakan sosialisasi atas programprogram desa.

"Kami mengkomunikasikan
program-program pemerintah desa
kepada masyarakat, termasuk mengenai
pengelolaan keuangan desa. Kami
mensosialisasikan kepada masyarakat
melalui musyawarah desa, kami
kumpulkan masyarakat dan kami
jelaskan tentang dana yang diperoleh
alokasinya buat apa". (Wawancara
Triyono, 18 Mei 2018)

Adanya upaya sosialisasi, maka tahap pertama dalam implementasi kebijakan perspektif Edward III yakni komunikasi telah terlaksana. Komunikasi yang baik, jelas, akurat, serta konsisten dapat dipahami dengan seksama dan tidak terjadi distorsi dalam pelaksanaan adalah bagian dari upaya bahwa kebijakan publik harus tepat sasaran, tepat guna, dan tepat anggaran sehingga pembangunan yang dilakukannya bisa meningkatkan kemakmuran rakyat. 
Pengelolaan dana desa yang tepat anggaran dimaksudkan untuk memastikan dana desa dilakukan dengan perhitungan yang matang. Namun, pada laporan keuangan Desa Ngesrepbalong Tahun 2017 ditemukan beberapa realisasi anggaran yang tidak sesuai dengan rencana anggaran yang telah dilakukan.

Penatausahaan atas pengelolaan dana desa pada Permendagri 113 tahun 2014 dijelaskan bahwa penatausahaan dilakukan oleh bendahara desa, sehingga bendahara desa wajib melakukan pencatatan setiap penerimaan dan pengeluaran serta melakukan tutup buku setiap akhir bulan secara tertib. Bendahara desa wajib mempertangungjawabkan uang yang dikelola melalui laporan pertanggungjawaban dan dipertanggungjawabkan kepada kepala desa setiap bulan paling lambat tanggal 10 bulan berikutnya. Dalam upaya melakukan pencatatan penerimaan dan pengeluaran uang menggunakan buku kas umum, buku kas pembantu pajak dan buku bank.

Di Desa Ngerepbalong dalam melaksanakan penatausahaan keuangan desa harus menetapkan bendahara desa yang dilakukan sebelum dimulainya tahun anggaran bersangkutan dan berdasarkan keputusan kepala desa. Bendahara adalah perangkat desa yang ditunjuk oleh kepala desa yang bertugas untuk menerima, menyimpan, menyetor, menatausahakan, membayar dan mempertanggungjawabkan keuangan desa dalam rangka pelaksanaan APBDesa. Selain itu bendahara desa juga memberikan laporan pertanggungjawaban tiap bulan sekali kepada desa paling lambat tanggal 10 bulan berikutnya.
Menurut Sofiati, Bendahara Desa Ngesrepbalong, dalam melaksanakan penatausahaan keuangan desa terdapat kendala dalam pelaksanaannya, seperti tidak semua transaksi pembelian terdapat bukti kwitansi, sedangkan untuk pelaporan membutuhkan bukti tersebut.

"Kendalanya saya selaku bendahara, cuma data dukung dari Tim Pengelola Kegiatan (TPK). Seperti, saatbendahara menyerahkan sejumlah uang kepada TPK.Dari TPK seharusnya dengan uang sekian menyerahlan kwitansi atau nota. Kebanyakan kalau membeli secara global (menyeluruh) sedangan kami mintanya tidak secara global, mereka belanjanya di nota belum ada pajaknya, tapi kami kalau laporan harus ada input pajaknya. Kadang kendalanya disana,TPK tidak paham menghitung pajaknya. Terkadang TPK dan bendahara harus musyawarah lagi untuk menginputkan pajaknya". (Wawancara Sofiati, 18 Mei 2018).

Pernyataan Sofiati di atas menunjukkan adanya dua kendala yang dihadapi bendahara dalam penatausahaan keuangan desa, yaitu pertama, tidak semua transaksi terdapat nota/kwitansi dan; kedua, nota/kwitansi yang sudah ada belum tentu sudah memenuhi ketentuan perpajakan.

Tidak adanya nota/kwitansi menjadikan kontrol terhadap pengeluaran keuangan desa menjadi lemah. Kwitansi adalah bukti transaksi yang bisa menunjukkan kemana uang APBDesa dibelanjakan. Tanpa nota yang valid, laporan keuangan bisa dipertanyakan dalam pertanggungjawaban keuangan dan bisa menjadi celah penyelewengan anggaran di lapangan. 
Masalah kedua mengenai pajak atas transaksi yang dilakukan. Pemungutan/pemotongan pajak penghasilan (PPh) dan pajak lainnya merupakan kewajiban Bendahara Desa ketika melakukan pembayaran kepada pihak penerima baik melalui TPK atau secara langsung. Kewajiban potongan/pungutan tersebut dilaksanakan sesuai ketentuan peraturan perundangundangan. Seluruh penerimaan potongan danpajak yang dipungutnya wajib disetor ke Rekening Kas Negara sesuai batasanwaktu yang diatur dalam ketentuan perpajakan (BPK, 2015: 86).Pemotongan Pajak adalah istilah yang digunakan pengenaan pajakpenghasilan (PPh) atas pengeluaran yang sudah jelas/pasti sebagaipenghasilan oleh penerimanya. Misal pengeluaran untuk gaji, upah,honorarium, sewa, dan pembelian barang atau jasa. Bendahara diwajibkan memotong PPhatas pembayaran terhadap penerima. Jenis-jenis $\mathrm{PPh}$ yang dilakukanpemotongan adalah $\mathrm{PPh}$ perorangan (PPh Pasal 21, dan PPh Pasal 23 UU No 36 Tahun 2008).

Pembelian barang dan jasa kepada pihak ketiga yang tidak memiliki Nomor Pokok Wajib Pajak (NPWP) Badan Usaha dan melakukan potongan pajak atas transaksi dikarenakan tidak semua badan usaha terdaftar secara resmi, misalnya warung, toko, dan jenis usaha kategori mikro kecil menengah (UMKM). Oleh karena itu, mudah ditemui transaksi pembelian barang/jasa yang tidak ada nota pajaknya.

Pada saat observasi lapangan, penulis menemukan bahwa laporan pertanggungjawaban diinformasikan kepada masyarakat dalam bentuk tulisan yang ditempel pada papan pengumuman di Balai
Desa Ngesrepbalong. Keterbukaan atas pelaksanaan program ini disampaikan Witoyo, tokoh masyarakat Desa Ngesrepbalong sebagai berikut:

"Sangat-sangat terbuka dan transparan, karena selain adanya sosialisasi kepada masyarakat sesuai dengan anggaran $R A B$ perencanaan, itu ada juga MMT pelaksanaan anggaran yang dilaksanakan itu apa saja, nilainya berapa, jadi supaya masyarakat mengetahui semua ini dana darimana, sumber dana darimana, habis biaya berapa, terealisasi berapa itu sangat terbuka". (Wawancara Witoyo, 18 Mei 2018).

Pelaporan program yang kegiatannya bersiklus tahunan misalnya pembangunan Balai Desa Ngesrepbalong yang dibangun dari APBDesa tahun 2015-2017, maka dari perencanaan, implementasi sampai dengan monitoring dan evaluasi juga dilakukan setiap tahun. Semua pengeluaran dan penggunaan dari APBDesa dibukukan sedemikian rupa oleh bendahara di Desa Ngesrepbalong telah sesuai dengan petunjuk yang ada dalam peraturan Kabupaten. Menurut Mibani (Wawancara, 18 Mei 2018), Sekretaris Desa, karena pembukuan sudah menggunakan Sistem Keuangan Desa (Sikudes) maka pembukuan keuangan menjadi lebih mudah. Mudahnya pembukuan ini juga memperlancar proses pelaporan dan pertanggungjawaban desa atas pengelolaan keuangannya.

Pada pelaksanaan Permendagri No 113 tahun 2014 di desa Ngesrepbalong menghadapi kendala, diantaranya: Pertama, sumberdaya aparatur yang kurang memadai. Indikasi ini dapat dilihat dari ketidaktepatan penganggaran pada APBDesa yang tidak sesuai 
aturan yang ditentukan(wawancara Triyono, 18 Mei 2018); kedua, adanya ketidaktepatan penganggaran tersebut menunjukkan fungsi kontrol BPD tidak berjalan secara maksimal. BPD sebagai wakil masyarakat desa dalam mengawasi berjalannya pemerintahan desa mempunyai tanggung jawab untuk memastikan kebijakan yang ditetapkan di wilayah desa sesuai dengan aturan yang berlaku. Nihlatun Nuha (Sekretaris BPD, wawancara 18 Mei 2018) mengakui bahwa BPD tidak terlibat secara langsung dalam pengalokasian dana desa dan akan terlibat jika ada kehendak dari kepala desa; ketiga, terdapat transaksi pengadaan barang atau jasa tidak menggunakan nota yang sudah memenuhi peraturan perpajakan. Sofiati (Bendahara desa, wawancara 18 Mei 2018) menjelsakan bahwa tidak semua transaksi pembelanjaan yang dilakukan oleh Tim Pelaksana Kegiatan (TPK) memiliki nota, dan anggota tim tidak paham menghitung besaran pajaknya. Oleh karenanya diperlukan musyawarah antara TPK dan bendahara dalam mengimput besaran beban pajak yang ditanggung.

\section{SIMPULAN}

Implementasi Permendagri No 113 tahun 2014 di Desa Ngesrepbalong secara umum dapat dilihat dari temuan berikut ini: (1) Pengalokasian dana tidak tepat sesuai dengan ketentuan; (2) Adanya ketidaksesuaian antara daftar program kegiatan yang telah disepakai dalam musyawarah desa dengan rincian kegiatan yang ada dalam tabel RKP; (3) Terdapat RKP yang tidak mencantumkan pembahasan mengenai evaluasi penggunaan keuangan tahun sebelumnya; (4) pada aspek trasnparansi, Pemerintah Desa telah melaksanakannya dengan menginformasikan pengalokasian dana dan perkembangan penggunaannya pada papan informasi di kantor desa. Adapun kendala yang dihadapi dalam implementasi Permendagri No 113 tahun 2014 di desa Ngesrepbalong antara lain : sumberdaya aparatur desa yang kurang memadai; fungsi kontrol BPD tidak berjalan secara maksimal; tidak semua transaksi pengadaan barang atau jasa menggunakan nota sesuai dengan peraturan perpajakan.

Adapun saran dalam menyelesaikan masalah tersebut; Perangkat Desa sebaiknya lebih memahami secara mendalam semua peraturan-peraturan yang berlaku khususnya Permendagri No. 113 tahun 2014, karena pelaksanaan APBDesa merupakan inti pokok dalam pengelolaan desa yang akan berdampak langsung dalam keberhasilan pemberdayaan, kemakmuran dan kemajuan suatu desa. Selain itu, Pemerintah perlu meningkatkan kemampuan aparatur desa melalui pelatihan maupun sosialisasi mendalam mengenai pengelolaan keuangan desa, sehingga tidak terjadi kesalahan administrasi dalam pelaksanaannya.

Dengan demikian akan mewujudkan pengelolaan keuangan desa sesuai yang diharapkan. Keberhasilan tersebut dapat terlaksana jika penetapan APBDesa dilaksanakan dengan baik dan perangkat desa memahami peraturan yang dijalankan, sehingga akan mempermudah dalam pelaksanaan APBDesa, dan untuk pelaksanaan APBDesa tahun mendatang haruslah dilaksanakan sesuai dengan ketentuan baru yaitu Permendagri No.113 tahun 2014 secara utuh. BPD sebagai lembaga yang mewakili kepentingan warga desa seharusnya lebih seksama lagi dalam mengawasi 
pelaksanaan pengelolaan keuangan dan program desa yang dijalankan. Dengan demikian program-program desa bisa tepat sasaran, tepat waktu, dan tepat anggaran.

\section{DAFTAR PUSTAKA}

Alhojailan \& Ibrahim. 2012. "Thematic Analysis: A Critical Review Of Its Process And Evaluation”. West East Journal of Social Sciences. Vol. 1 No 1

Arif, Muhammad. 2007. Tata Cara Pengelolaan Keuangan Desa Dan Pengelolaan Kekayaan Desa. Pekanbaru: ReD Post Press

Aswandi, M. Sulpan. 2014. "Kedudukan Peraturan Desa Ditinjau Dari Undang-UndangNomor 6 Tahun 2014 Tentang Desa”. Jurnal Ilmiah. Mataram: Fakultas Hukum Universitas Mataram

Atkinson (Eds.). 2001. Handbook of Etnography. CA: Sage Publication

Aziz. S.R. \& Abdul. 2003. Memahami Fenomena Sosial Melalui Stud Kasus. Jakarta: PT Raja Grafindo Persada.

Badan Pengawasan Keuangan dan Pembangunan. 2015. Petunjuk Pelaksanaan Bimbingan dan Konsultasi Pengelolaan Keuangan Desa.Jakarta: Deputi Bidang Pengawasan Penyelenggaraan Keuangan Daerah

Ferina, Ika Sasti, Burhanuddin, dan Herman Lubis. 2016. "Tinjauan Kesiapan Pemerintah Desa dalam Implementasi Peraturan Menteri Dalam Negeri Nomor 113 Tahun 2014 Tentang Pengelolaan Keuangan Desa”. Jurnal Manajemen dan Bisnis Sriwijaya Vol.14 No.3

Hanif, Nurcholis. 2011. Pertumbuhan Dan Penyelenggaraan Pemerintah Desa. Jakarta: Penerbit Erlangga

Ikatan Akuntan Indonesia. 2015. Pedoman Asistensi Akuntansi Keuangan Desa

Islamy, M. Irfan. 2009. Prinsip-prinsip Perumusan Kebijaksanaan Negara. Jakarta: Bumi Aksara

John W. Creswell. 2011. Research Design: Pendekatan Kualitatif, Kuantitatif, dan Mixed.Yogyakarta: Pustaka Pelajar

Kementerian Keuangan Republik Indonesia. 2016. "Kebijakan Pengalokasian dan Penyaluran Dana Desa Tahun 2017", disampaikan dalam workshop mengenai penyusunan Rancangan Peraturan Kepala Daerah mengenai Tata Cara Penghitungan
Pembagian dan Penetapan Rincian Dana Desa TA 2017 di Redtop Hotel and Convention Center, 2124 November 2016

Kementerian Keunagan Repiblik Indonesia. 2017. Buku Pintar Dana Desa: Dana Desa Untuk Kesejahteraan Rakyat. Jakarta: Kemenkeu

Miles, M.B. \& Huberman, A.M. 1994. Qualitative Data Analysis. London : Sage.

Moleong, Lexy J. 2007. Metodologi Penelitian Kualitatif. Bandung: Penerbit PT Remaja Rosdakarya Offset

Nugroho D, Riant. 2004. Kebijakan Publik: Formulasi, Implementasi, dan Evaluasi. Jakarta: Gramedia

Pasolong, Harbani. 2010. Teori Administrasi Publik. Bandung: Alfabeta

Peraturan Menteri Keuangan RI No 241/PMK.o7/2014 tentang Pelaksanaan dan Pertanggungjawaban Transfer Ke Daerah dan Dana Desa

Peraturan Pemerintah No 6o Tahun 2014 tentang Dana Desa

Permendagri No 113 Tahun 2014 Tentang Pengelolaan Keuangan Desa

Profil dan Potensi Desa Ngesrep Balong, 2015

R. Bintaro. 1983. Interaksi Desa - Kota dan Permasalahannya. Jakarta: Ghalia Indonesia

Ritchie, J., \& Lewis, J. 2003. Qualitative research practice. A guide for social science students and researchers. London: Sage Publications

Salim, Agus. 2001. Teori dan Paradigma Penelitian Sosial. Yogyakarta: Tiara wacana

Soetardjo. 1984. Desa. Yogyakarta: PN Balai Pustaka Stake, R. 1995. The art of case study research. CA: Sage

Stoner, James A.F. 2006. Management Englewood Cliffs, N.J.: Prentice Hall, Inc

Tangkilisan, Hersel Nogi S. 2003. Kebijakan Publik yang Membumi. Yogyakarta: YPAPI

Undang Undang No. 6 Tahun 2014 tentang Desa

Voismoradi, et.al. 2016. "Theme development in qualitative content analysis and thematic analysis". Journal of Nursing Education and Practice, Vol. 6, No. 5

Widjaja, HAW. 2003. Pemerintahan Desa/Marga. Jakarta: PT. Raja Grafindo Persada

Widodo. 2010. Analisis Kebijakan Publik: Konsep dan Aplikasi Analisis. Malang: Bayu Media

Winarno, Budi. 2011. Kebijakan Publik: Teori dan Proses. Yogyakarta: Med Press 
Yin, R. K.. 1994. Case Study Research Design and Methods: Applied Social Research and Methods Series. Second edn. Thousand Oaks, CA: Sage

Zulfan. 2014. "Implementasi Kebijakan Program

Pendataan Keluarga Sejahtera Dalam

Pendistribusian Alat Kontrasepsi Di Kabupaten Sintang”. Jurnal Administrasi Publik dan Birokrasi

Vol.

No.

2 